\title{
Initial Film Rhetoric: Catastrophe Measurement and Visual Estimation
}

\author{
Alexander P. Liusyi* \\ The Heritage Indtitute \\ 2 Kosmonavtov Str., Moscow, 129366, Russia
}

Received 29.03.2016, received in revised form 18.04.2016, accepted 05.05.2016

The Crimean text originated as the South Pole of the Petersburg text. In the process of its genesis Semyon Bobrov's cumbersome poetics was absorbed by Alexander Pushkin's poetic ease. As for literary "film poetics", it is of the Crimean origin, and Bobrov remains unrivalled here, especially in the poetics of catastrophism. Later mythology of selfdenial turned to be especially inherent to two cities in the world, the cities being Petersburg and New York. Catastrophism was strengthened by cinematographism in both cases. Regarding the Petersburg and Moscow texts, the strengthening was due to cinematographism of the word but not due to real screen adaptations. In particular, it was Andrew Bely who had specific cinematographic thinking. He created film poetics in his novels "Petersburg" and "Moscow". This poetics was far ahead of the real development of cinematography of his and even our time. The paradox is that no one aims at screen adaptation of Bely's novels. They limit themselves to Vladimir Sorokin, who turned out to be closer to the capital that came alive again as office and raw Phoenix (Moscow as New Petersburg of New Russia).

As for New York, thanks to cinematography it has long been a symbol of the city destroyed by all sorts of catastrophes. "September 11" is neither more nor less than a symbolic repetition of many scenes from catastrophe films. Imaginary disasters till 11.09.2011 compensate for a monotonous rhythm of everyday life, whereas after this date they virtualize a radical experience and function as an emotional protection, formed by a daily monotonous rhythm. However, the response to the terrorist attack at the state level was akin to the cowboys' reaction to early westerns when they fired at the screen. In Russia catastrophism is not as much gets its cinematographic adaptation but it is added to the category of museum ehxibits by the media. The launch of the mechanism of formation of a global screen room is shown in the finale of Balabanov's "Morphine" film.

Keywords: poetics, film rhetoric, metaphor, editing, classifications, catastrophe, medium, text, film industry.

The article is supported by RHSF grant № 15-03-00581 "Development of space representations in cultural practices: history and the present" and № 15-33-14106 "Goals of state national policy: human resource resumption and national cultures (the problem of the Other)".

DOI: 10.17516/1997-1370-2016-9-5-1198-1209.

Research area: philology.

(C) Siberian Federal University. All rights reserved

* Corresponding author E-mail address: allyus1@gmail.com 
The idea of nature in philosophy becomes exhausted by neither physical nor metaphysical meaning nor cognitive attitudes. "It exhists as a cosmological idea as well as something aesthetically significant, which is an "idea" of art and a subject of practical relation of both cultivation and use (a source of energy and raw materials) as well as the "environment" that needs special preservation and a special world opposed to the world of urban civilization" (Akhutin, 1988, 13). Nature is a meta-cultural phenomenon, multidimensional place of crossing different cultural energies that could lead to a disaster.

\section{A scroll of potential screen}

Artistic discovery of nature dates back to the XVI century, to the Baroque era. It was very far from being to some extent idyllic. Nature was seen as some (a favourite phrase of the poetprecinematographer who will be mainly dwelt upon below) immensity and blind power opposing culture and culturing. Nature does not open here but opens wide in front of a human as an abyss permeating and embracing all forms of culture. On the one hand, it must be subject to reading, being regarded "as a book of secret words". On the other hand, it intrudes into a verified text of a lecture or prayer type with wild news. It squeezes in the statue with a rough, raw piece, thus, being vaguely, persistently, fatally present. "Nature - which is both nature of a human, nature in a human - is opened in the XVI century the way they open a tragic show. Only a tragic talent - Shakespeare, Michelangelo, Bruno - can show this discovery (i.e. announce it) artistically. These are not pastoral naturalness, solitude in the bosom of nature but "heroic fury" of painfully unrequited love and hopelessly endless hunt that interprets open nature. Anxiety for knowledge takes the ancient Eros's place" (Ibid., 41).

Nature would probably have remained a subject of artistic perception and aggressive adventures; it would never have become the subject of scientific knowledge, if its discovery had not created special forms of contemplation. In its material existence nature is an infinite multiplicity of forms and differences, eluding any exact measurability. "But can darkness be measured?" is a typical question arising in the course of poetic estimation of nature, the estimation being "Taurida" ("Khersonida"), a poem by Semen Bobrov, a representative of the late Baroque in the Russian poetry (appr. 17651810).

To cognize nature it is necessary to find an opportunity or occasion to bring the infinite into the finite, to focus it on a single. "We perceive nature behind action where it is forced to operate in cramped circumstances and it has to reveal the form of its action proper. And this means that nature is being studied with precise dissection and anatomy, and it is the focus at which we must understand another Baonian definition of the method to cognize nature, namely its interpretation" (Ibid., 76).

In my previous work I followed a number of other researchers and paid considerable attention to S. Bobrov's poem "Taurida" ("Khersonida" in its second edition (1804)), the only "descriptive" poem in the Russian literature with its shade of natural philosophy. Substantial addition to understanding of essence of this work has been recently done by L. Zaionts. Semyon Bobrov, the first poet of Taurida, poetic Columbus of the Crimea, also appears as a founder of the Crimean movie text.

The Crimean text originated as the South Pole of the Petersburg text. In the process of its genesis Semyon Bobrov's cumbersome poetics was absorbed by Alexander Pushkin's poetic ease. As for literary "movie poetics", it is of the Crimean origin. According to L. Zaionts, Bobrov remains unrivaled here, even in the context of the problem which was defined as "Pushkin and 
editing" by Sergey Eizenshtein in connection with a "dynamic characteristic of the image" (Eizenshtein, 1988, 87).

The poem "Taurida" by S. Bobrov, Pushkin's predecessor, is "based on the principle of editing of two genres: an encyclopedic description of the Crimean geography, geology, flora and fauna and an allegorical story of two pilgrims, a sage and his young disciple, symbolizing the starting and final points of a life cycle" (Zaionts, 2012, 261).

The "scroll of nature" metaphor acquires the properties of both an active poetic model and an unfolding screen. The time of the narrative is modeled here as a continuous spatiotemporal flow from sunrise to sunset. "...The effect of "visual" (spatial) continuity ensures and delegates a role of an operator-chronicler to the lyric subject (the author). He is likely to follow the same route as a pilgrim, but his point of view is dynamic and free, the view being that of a film character. The formalists consider his difference from a theatrical character to be in his "existence in the infinite space and moving freely in it" [Eikhenbaum]" (Ibid., 262).

It is not only a wanderer who roams: "The eyes will be wandering here / In the variety of countless sights". The "objective lens", point of view, which is the protagonist of the poem's narrative, is moving. The illusion of constant movement in time and space is supported through certain "pedestrial" connectives that are rhythmically distributed throughout the text of the poem: "I'll walk along a smooth plain..."; "Why to delay? - we'll hurry out of here! / For those rocks..."; "Crossing Usliuksky dales <...> / I'm gazing at two long capes...", "Behold! - There's a path to the banks - / to which the darkest way is taken...", "Oh, how blessed he is who rises / On top of your, Argenis, pride / Through willow bushes...".

According to L. Zaionts, an aesthetic effect, anticipated by the author, is mainly focused on visual abilities of imagination. Bobrov encourages the reader to look and see: "A Stranger! Traveller! - A viewer! - Come here and see!...”; "You see the bushes here under the sky... / And wide-trunk beeches there..."; "How curious it is to contemplate... / The shadows that through all nights are running...", "What mysterious views / A searching eye will find / In morning and in evening hours...", "But I'm lost in the ocean / Of different changing scenes".

As stressed by L. Zaionts, the term "view" means "neither a view transferred to a canvas, nor even a projection obtained with a pinhole camera. For Bobrov it is a search for the methods, transmitting depth and multidimensionality of space. Bobrov's “view” is a variable view, i.e., both changing and seen from different points of view. His view is stereoscopic: the same panorama can be given from several angles, in different planes and at different scales" (Ibid., 263).

Transmitting an overwhelming size of the Chatyrdag mountain, Bobrov edits opposite angles in one verse - upward ("It seems to me, the tops are covered / Not with the groves but with the glaze") and downward ("The dale seems to be besprent / Not with the bushes but with small grain"). The stanza "Such is the eye in the mountains!" draws a final line.

The author cannot tear his eyes from a central part of a circular panorama of the peninsula. There are "three noisy abysses" near three picturesque coastlines - western (Yevpatoria), eastern (some distance away from Sudak) and the Azov Sea shore. Another non-trivial resource is involved to complete the impression. It is the swimmers' view from the sea. "This mountainous shore" seems an unknown land from here, but "how pleasant is the delusion".

It is worth while proceeding with these observations, paying attention to Bobrov's historiosophical views. Below is a lengthy scenario fragment of song $\mathrm{V}$ of the poem which 
is about historic trials of the peninsula and the "desperate hermit's" god-fighting doubts on these issues.

Indeed? Are dreams curling indeed?

Haven't the phantoms risen? -

Who you are, awful Genesis?

Are you a dream? - or a deity? -

Or Genius of the mountains? Or heaven's

angel? -

Or spirit of the forefathers? -

Son of rock! - open up before me!

Dispel the darkness of imaginations!" -

A desperate soul! - an angel

Thundered under a gloomy vault of heaven:-

It is the father of spirits speaking;

What makes you almost drown in thy scornful thoughts?

You err, - a man!;

You're unknown to yourself; -

Damn thy desire,

Which is to be nothing! -

A son of mortal flesh! -

How dare you be nothing! -

What is it to be nothing, - give your

answer! -

But you can't respond...

Ah! - how dare you, ill-fated son,

Have such a wicked wish.

May shortness of thy days reduce,

In course of which thy spirit had not

Learnt its lessons yet? -

You'd better just surrender to the

Providence!

Shut up! - and learn, - be patient! - and obidient, -

And be on the alert of blow! but not the way you are; ...

It is not in thy will...”.
The following song, song VI, gives a large-scale descripton of the storm over the Crimean Mountains. Its rampant voice is nothing compared to "all the sounds of copper in the world of dale". The song continues the arguments about the scale of divine victims during the punishment of individual criminals of thought (there is a detailed description of G. Rikhman's death during the experiments with electricity and M.V. Lomonosov's regret for it).

Previously, basing on A. Pushkin's numerous creative borrowings from the lines of "Taurida", the borrowings being proved by the researchers, we assumed that Bobrov's multiple uzhel' ("indeed", "if"), that expresses doubts, sets the way for Pushkin's uzho, that expresses threat in "The Bronze Horseman". The difference was in the following: the revolt of Peter I's spirit against self-destruction of "immortal identity" and "heavenly inwardness" is not of a fatal but of an educational character.

Cinematographic proof of this hypothesis would be possible with the method of "fadein", the method given great attention in K. Metz's "The Imaginary Signifier". "In the case of influx, which is a superposition of two objects, approaching in its character to the sequence, as one image eventually replaces another, the primary identity of the two motifs is, to a lesser extent, a condensation and, to a greater extent, an offset. However, the common for these two figures are also the fact that they transfer the mental load from one object to another (rushing in the direction opposite to any day's logic) and the fact that they generally or in a residual form represent predisposition of a primary process to eliminate the very duality of objects, in other words, to establish those closed magic circles, required by our desire devoid of any ability of expectation, beyond the divisions imposed by the reality" (Metz, 2010, 153). 
Reasonings about a metaphoric and/or metonymic character of "influx" (as if visualizing the image of birth/death) are interesting in relation to a possible cinematic reading of S. Bobrov in the natural philosophy context. Is influx a condensation or displacement (i.e. metaphor or metonymy)? "The relation is metaphoric if one of the two images is extradiegetic, it is metonymic if they both represent the aspects of the same activity (or same space, etc.), and it is dual if one of these aspects resembles the other, compared with it and, in a sense, connotates with it, etc. It is impossible to attribute all kinds of "influx of one frame to another" to the metaphoric principle, as not all of them have a comparability value. This brings us to a central problem of our research, the level being a different one. The problem is that of intersecting classifications: if each case does not necessarily use one single generating principle, we can so much the less expect that whole categories (such as "influx", on the one hand, and "metaphor", on the other hand) will exactly match each other since they were introduced in different practical fields (and, what is more, in historically unrelated areas of knowledge). It is important here not to rely on their coincidence but to analyze the ways of their intersection" (Ibid., 218).

S. Bobrov's intersecting natural and historical classifications reach, according to our plan, their interpretive climax at the influx of the Crimea and Petersburg that is grounded in the idea of a genetic origin of the Crimean text as the South Pole of the Petersburg text. K. Metz shows that the influx ensures a more detailed and lengthy observation of the movement than the frames proper (or their apparent breakage), the movement marking the transition from frame to frame in a film, when the moment of transition is exaggeratedly lengthy, which, in itself, has a value of metalinguistic commentary. "Moreover, having slightly delayed at the bifurcation point of the text, the film draws our attention to how it creates its own fabric, how it constantly adds something to itself.

However, the condensation process is also present; yet, it just happens in a different place, though still "inside" the figure. It is in a (momentary, fleeting) co-presence of two images on the screen within that brief moment when they become indistinguishable (refer to the notion of Freud's "collective characters" that he mentions in connection with condensation). This initiation of condensation, having the only difference of representing a kind of precipitate that never precipitates. In French they speak about the figures that "are being born", thus, the influx in terms of condensation is a dying figure which is dying from the very beginning. This is its difference from a lengthy and persistent superposition): two images should meet, but they go to meet turning their back to each other. If condensation is getting clear, it is so as it gradually fades away. As image 2 becomes clear, "apparent", the image fades away, "leaves". It is like billiard balls: when they meet, they immediately repel each other. But still they "come in contact" for a moment. This is condensation which is on the verge of disappearance" (Ibid., 311-312).

$\mathrm{K}$. Metz puts a question whether the influx is a primary or secondary process as well as whether it is metaphor or metonymy, or both at the same time. "In this case everything depends on the relations between the source and destination images. When they merge in order of the plot development or on the basis of sustainable relations of adjacency, what both the director and the audience know about, the development of influx is metonymic. If it is based on similarity or contrast it is metaphoric. It is often dualistic, and this is no accident: the items can be close to each other and at the same time resemble each other; both criteria do not exclude each other, the categories they designate are not optional, they 
intersect (while remaining different as in the theory of sets).

I should add now that the influx, which is not purely metonimic, demonstrates a remarkable metonymic ability. If it can be put like this, it aims at post factum creation of an initially existing link. (Actually, this link sets the offset "behind" the influx, but the result is the same.) Metonymy connects two objects that are in relations of referential adjacency; and the power of transitivity inherent to the influx as well as text adjacency, which it actually operates with (emphasizing it with a slow and gradual nature of shooting), to some extent deprive the spectator of freedom to think that both elements, united like this, could have no adjacency in some referent. That is, probably, the reason of confusing editing with metonymy. The influx seems to be able to give the purest metaphors a metonymic form. Thus, the influx gives us a sort of magnified image of what happens in linguistic metonymy: it chooses one adjacency out of the many possible and equally "referential" ones, but the power of a metonymic act predisposes us to assume that this adjacency is more pronounced, more visible and more important than the rest. The influx operates in a similar way. It is even of a larger scale because it shows its way (= opposed to linguistic metonymy) and also due to the fact that possible adjacencies in movies are much more numerous as the choice between them is even of a more arbitrary nature" (Ibid., 314-315).

\section{Random medium}

The literary cinematographic nature of the text is far ahead of technological capabilities and aesthetic principles of real cinematography. If to recallD. Vertov's dichotomy, the latter is somewhat similar to the linguistic controversy between the "Shishkovists" and the "Karamzinists". Thus, it followed the way of a "psychological" movie but not of a "movie eye". It is only nowadays, with the emergence of 3D technologies, when the film version of Bobrov's works becomes possible. Similarly, Andrey Bely's novels, built on the principles of film poetics, remain not subject to real cinematography.

Whereas Bobrov and Pushkin were pioneers of an offsite tourist version of the Crimean text of the Russian literature as the South Pole of the Petersburg text, it was Vladimir Nabokov who became a conductor of a departing Crimean movie text as a subtext of an analogous consolidated supertext of the Russian culture. V. Nabokov based all his power of literary talent on a number of samples of his prose, from "Mashen'ka" to "Lolita", etc., not only on Pushkin's "nereids" but also on Evgeny Bauer's film "For happiness" (1917). This is demonstratively and in detail described by I.P. Smirnov in his book "Video sequence. Historical semantics of cinema" (Smirnov, 2009). The movie text was formed as a text of culture on the basis of its medial movement from Pushkin's Nereid to Nabakov's Lolita, the landscape of "Russian Riviera" being in the middle. Like Semyon Bobrov's "Taurida" in literature, the film "For happiness" is an establishing phenomenon of the Crimean movie text.

This film turned out to be "super productive" for visualization of the Russian literature and culture in general. It sets a paradigm of a new love triangle of the modernist era, the triangle being that of a man, a woman and her young daughter. In fact, Semyon Bobrov in his "Taurida" also described a similar triangle, but in a broken form. "Taurida" (1798), the first version of his poetic encyclopedia of the Crimea, introduced the Crimean theme to literature immediately in its highest expression. Zarena, an addressee of his love poetry messages, is clearly of local origin (Pushkin, as it is known, changed only one letter in the name of his heroine in "The Fountain of Bakhchisarai"). In "Khersonida", the second 
version which was published six years later, the name of a beloved is Sashena (she waited for the poet somewhere in the North, from where she perceived his calls and warnings in the "East is a delicate matter" spirit). Such is the pretext of "hidden" love, or loves? It is the pretext, created primarily from figures of speech but not from real prototypes.

The plot of a "psychological" film "For happiness" is quite simple. Zoya Verenskaya and Dmitry Gzhatsky, a lawyer, were in love for many years. Still, Zoya gave up the happiness of being together not to hurt her daughter Lee who kept on adoring her father. In the Crimean resort, where Zoya took her daughter to heal from an eye disease, it suddenly became clear that Lee was also in love with Gzhatsky, thus rejecting the love of Enrico, an artist painting her portrait (the role of Enrico was played by Lev Kuleshov, a future film director). On her return, wishing happiness for her daughter, Zoya begged Dmitry to respond to Lee's love but he had no strength to make such a "sacrifice". Having failed to overcome a nervous breakdown, Lee got blind.

Bringing the story of Larina's youth closer to the film "For happiness", the poet had his own way of giving his due to the film with the desire to mirror the melodrama rising above the genre in attempts to engage it in the field of image. Melodrama in Bauer's film results in the fact that Lee with her weak eyesight does not meet the terms of a medial and symbolic order with the reign of cinematography. She becomes totally blind by the end of the film. It is only in the film where she has eyesight. However, she is punished for her incestuousness with the same disability which Sophocles' Oedipus punishes himself with. At the same time one of the director's literary landmarks could possibly be "The Ancient Night of the Universe, or a Wandering Stanger", the second poetic epic of Semyon Bobrov, a literary Columbus of the Crimea. It is more likely so if we take into consideration that the books by this supposedly "forgotten" poet, according to some philologists, were always on the desk of such a film fan as V. Mayakovsky (Vaiskopf, 2003).

D.N. Zamyatin in his essay "Lolita's economic geography" noted that "the landscapes of this letter are oppressively tropical". Thus, he gives the formula of ascension of a pseudonymous Crimean text in its postulated dialectics from Nereid to Lolita, the formula being similar to the Marxist-Eisenstein scheme: "Trope, path, paths, tropics, tropic of cancer" (Zamyatin, 2004, 396). Then there is the following geopoetic observation: "Nabokov's Russian poetry: prose-like clumsy monsters; the sight of primitive immature texts, geological sections and exposures of future geographic outlines of a perfect prose of travelling in their unclear, vague, still early relief”. Terribly muscular metaphors, forced-made poetic meanings. Revelation of the Russian poetry.

Writing: fate and vice. Immorality of text, text as a literary debauch. The vices of writing, immorality of texts" (Ibid., 404).

What he wrote about the prose was the following: "Lolita is a mountainous region; abysses, passes, canyons, rocky mountains which are barren, burnt by the bright sunlight, trembling, and shivering in the haze of images" (Ibid., 388). Prose grows out of poetry, America - from the Crimea, and the medium in the dialectic of Nereid/ Lolita is Bauer's Gurzuf screen adaptation. What is a "film" compared to other cinematographic genres? Is it a visible film, narration, movie material, techniques of film-making, special camera work, editing, lighting or "la Cinema" (Metz)? Or is it film industry in general with its hierarchy and stereotypes, love of the audience, special cinema architecture, whole composition of order of eyesight and construction of view, with the "dispositive"? In reality the medium of "film" is inseparable from all these elements. Yet, 
the attempt to bring the movie to a certain chosen list of these components would be equivalent to his rate setting. However, recognition and consideration of all these elements turns it into an infinite series of intermedialities. And this makes it possible to talk about "form" of the media and about the media of "forms", i.e. about the "form of the forms" in Luhmann's terms, endlessly complicating it (Mersch).

\section{Mercury light, blue light, white light: to the last influx}

Let us come back to the idea of "catastrophic" influxes. Petersburg and New York are two cities in the modern world with their particularly inherent mythology of denial. Whereas any text of the city has a nuclear structure, the structure of Petersburg and New York as texts is rather thermo-nuclear. In both cases catastrophism is strengthened by cinematographism. As for the Petersburg (and Moscow) texts, it is strengthened by cinematographism of words, but not by real film version.

"Cinema, - Benjamin writes, - is a form of art that corresponds to constantly increasing threat to life, the threat which modern humans cannot ignore... It seems that we are offered what is regarded to be the subject of Heidegger's theorization in his "Origin of the Work of Art", when he dwells on the concept of Stoss (a shock.A.L.). This is done in a funny demythologized form, reduced to the level of everyday life (traffic with its dangers). Although for Heidegger the effect of shock, provoked by art, is associated with death in a completely different sense, he is, probably, close to what is meant by Benjamin. The matter is not so much about some risk of being run across by bus on the street, but about death as a constitutive possibility of existence. According to Heidegger, what is provoked by Stoss in our experience of art is that very fact that a piece of art exists as our "being not here" (Vattimo 2003, 58).
Andrey Bely's prose is notable for his unrealized cinematographic potential.

On the one hand, the novel expresses the limits of artistic expression. On the other hand, it signifies a new ideological attitude which is consistent in its deformation, taken inside, and superimposed on former "capital" ideological confrontations. Moscow winter is described as if with trembling eyelashes of a transformed eye and language: "The fridge jerked to turn everything into iron; the roofs were drummed with; the snowstorm blizzed in the pipe; the eyelashes were showered with screeching flocks of gnats; everything is semi-precious outside the window: mercury light, blue light, white light!" (Bely, 1989: 88).

All former components of the "Moscow myth" turned inside out in Bely's "Moscow". It is done not without help of models of the Petersburg text (the characters of "Moscow" are reincarnations of the "Petersburg" characters). "Damned", "hanging over Tartarus" Moscow is in place of "holy" Moscow. Entirely "philistine", "vulgar", "dirty" Moscow is in place of "domestic" Moscow: "A man flashed, sneezed, wailed, squealed, snorted, shuffled here, being made up of timid figures that emerge from the gates and entrances of baked all over and nonaired life". "Decrepit", "painful", "tumor-like" Moscow is in place of "natural, organically grown Moscow": "Moscow... A big old woman, knitting her millennial and fateful stocking"; "the embodied tumor, interlaced with an allround lane network". "Everything was distorted and shifted here".

Preparing a large fire/explosion of Moscow, A. Bely mystifies the reader with a parody game with Moscow toponymy as if removing a real topographic vision of the city in favor of grotesque. "Moscow! It has scattered high, small, medium, golden-domed or pillarless twistdomed churches of different eras; under the dust 
of heaven there are green, red, flat, low or high roofs of plastered, glazed or simply dressed in rags of fallen lime houses, "sitting" in the trees, or entire columnar or pillar-less, balcony-type, with acanthuses, caryatids that heavily support cornices and balconies, pedimental triangles of houses, large houses and small houses Liuliukhinsky and Tabachikhinsky - neibouring with the first, second, third, fifth, fourth, sixth and seventh Gnilozubovsky lanes" (Ibid., 24-25). It neighbours with the string of many-colored houses, sign-boards ("krendel" (knot-shaped buiscuit), "Zolotoi sapog" (golden high boot)) and cacophonic onomatopoeias of a "drumming" and "grinding" street. This, similar to cataloguing of an architectural disorder of the Moscow city ensemble, brings Bely's passages together with a style beginnings of the early "pre-revolutionary" avant-garde which is not only pictorial. Rapid movement of a viewpoint along the streets is a sign of a cinematographic nature of the look. A. Flaker notes the practice of "Zapiski chudaka" (“A Queer Old Fellow's Notes") (1922), in which the "spies", especially in London, shot the narrator on "the tape". This is evidenced with the "flashing of images" presenting "sign-boards" and "billboards" (Flaker, 2008, 178).

Moscow as a subject of description perfectly satisfies the needs of new poetics. Similarly, in his letter to M. Buber V. Benjamin dwelt on his attitudes to the description of Moscow: "My descriptions will avoid any theory. I hope that thanks to it I will manage to make the reality talk... I want to depict this city, Moscow, at the moment when "everything, which is actual, has become a theory", and, therefore, it is beyond any deductive abstraction, any prognostics, and, to some extent, any evaluation at all..." (Benjamin, 1997, 9-10).

The "Moscow" novel "is written by the author with the already "exploding head". It is about people (having their evident prototypes) who lived before the birth point of a new "myth". Therefore, the unbroken holistic world is looked at not with a normal human eye, but with the cloud of atoms of the scattered brain, the cloud with an apparent genius for the world description... And if Bely himself told his readers that his "new font of a new alphabet" had partially "fell into a hubbub of old letters"..., we have every right to regard these words as the author's metadescription of the structure of the text "Moscow" and especially of "Moscow Eccentric"” (Katsis, 1999, 140).

However, the "scattered" font and "exploding" head, an explosion of language and a fire of genre (fire as the main genre of the Moscow text) does not scatter the text of culture which is spontaneously composed on new grounds and, in any case, predetermines such crumbling composition due to cinematographic thinking that runs ahead of the development of real cinema of that time as well as of our time (the attempts of film adaptation of A. Bely's works are unknown). Combination of literature and cinema in the word, which is manifested in "Petersburg" experimentally sharp, was essentially developed in "Moscow". Images and details here differ by brilliance of a great number of colors and shades, a graphic clarity of line, volume. "Kaval'kas shouted with his red vest; his tumescent face clearly shimmered in bluish green colour; the princess cried with her bright green trousers; Vishnyakov turned as yellow as ginger" (Bely, 1989, 337). For Bely the characters' speech was something minor compared to gestures, posture, facial expressions, outlined carefully and in detail. The "Moscow" characters' gestures are grotesque, exaggerated". "Like a tiger, he suddenly jumped off lightly, throwing a briefcase and a stick with a shining tip to a young man's hands" (Ibid., 25). A swift, lightning-like rhythm was synonymous to the silent cinematography". Bely partly portrayed private complex gestures, crushing into several "atoms", each of them being 
a holistic visual image with a specific plastic and dynamism - a film frame. "He stood up and went filing into the room with his special hop, dancing with himself and dancing in front of a humble servant while giving him an (unnecessary) order to hear the submissive:

- Yes, sir!" (Ibid., 283).

The complex gesture of Mandro crushes into quickly successive "atoms" - the frames: "fell out", "went filing", "dancing with himself", "dancing in front of a humble servant".

Eccentric, caricature, lightning-like gestures can displace the characters' tongue-tied speeches. Combining the talent of a writer and a filmmaker, Bely skillfully operated with the change of projections. The Kunetsky most view, shown as if from a height, panoramically ("a wave of bowler hats, hats, caps, furs, mantles, blouses", rapidly gave its way to a close-up of a face with hyperbolically highlighted detail of appearance, portrait ("the gaze", that is a viewer's eye directed at the reader) (bright red lips, a sparkling earring), and then to a midshot (human figures - "eastern people in small bowler hats"). The background is also seen, the background being "piles of crushed bodies stuck to the shopwindows" (Ibid., 87). "Moscow Eccentric" and "Moscow under Attack" are novels-screenplays marked with the influence of expressionism, Bely being its founder in literature and cinematography.

Strangely enough, none of the directors aims at Bely's novels adaptation. Vladimir Sorokin's works turned to be closer to the capital reborn as office raw materials Phoenix (Moscow as new Petersburg of new Russia).

As for New York, it is due to cinematography that it has long been a symbol of a city destroyed by all sorts of catastrophes. "September 11" is neither more than a symbolic repetition of many scenes of the film-catastrophes. Imaginary catastrophes till 11.09.2011 compensate for a monotonous rhythm of everyday life, and after it they virtualize a radical experience and function as an emotional protection formed by a daily monotonous rhythm. However, the response to the terrorist attack at the state level turned to be akin to the cowboys' reaction to early westerns when the cowboys shot at the screen. The result of the invasion of Afghanistan and forcing the Taliban from their power was turning the country into a major drug supplier. This set is naturally added with a the number of new Russia's cities slowly decaying as a result of de-industrialization and struggling to survive in their narcotic convulsions, the voice of these cities in poetry being that of Boris Ryzhy. Catastrophism here is not so much made cinematographic but represented as a museum exhibit. The launch of the mechanism of a global screen room of "narcissistic identification" formation (Omon, 2012, 197) is brought out in the final of "Morphine”, A. Balabanov's film.

Technological catastrophism is the highest and final stage of engineering utopianism. This is not only the activity in anticipation or prevention of technogenic catastrophes, but primarily the type of thinking itself that focuses on providing and equipping a human's creative position in a situation of a lasting catastrophy. This is a vision of the world as constantly and radically changing and artificially changeable reality, which Homo sapiens faces in all his nakednes.

Whereas the "projects" of J.P. Sartre, a molder of opinion of the rebellious youth of the sixties, such as "love project", "friendship project", etc. ended with naturally and planned failure, the belief of R. Fuller, his contemporary, an American architect and life builder, in the possibility of new forms of sensuality and interpersonal relations in the American counterculture of 1960-70s resulted in "technical" attitude to the events. R. Fuller is a clear prototype of a wise and experienced "old man" in Hollywood movie utopias of the early 80 -s, teaching young mutants the basics of Vita Nova after a nuclear apocalypse. 
However, it is worth while remembering the elder Sheriff from S. Bobrov's "Taaurida", who gives his young disciple Mirza the lessons of positive catastrophism. "With all the totality and universalism of technological projectivity claims Fuller's worlds are always local isolates, "shields" from a "stormy world", whether these are small "domes" for "children of flowers", Manhattan under the cap creating microclimate within the boundaries of the whole urban area, or a project of a geodetic shell around the earth, designed to protect a fragile planet from space disasters. This is evidently a direct opposition to the "environmental vision", and at the same time the most important intention of technological projectivity since globalization is possible due to the growth of the physical scale of "objects" but not due to the shift or accumulation of thought and action techniques. Engineering has run out of means of considering the world as the rational management material. This has caused a desire to design in extreme conditions and a specific ability to present any conditions as extreme ones" (Kapustin, 1995, 57).

Thus, modern technogenic world is in need of a universal catastrophe. It is against its background that the world acquires its significance and persuasiveness, including aesthetic one; and modern cinematography is turning into the industry that serves this need. It is most likely that media were originally based on this need.

\section{References}

Akhutin, A.V. (1985). Poniatie "priroda" vantichnosti $i$ v Novoe vremia ("fiusis" $i$ «natura») [The Concept of "nature" in antiquity and modern times ("fuses" and "nature")]. Moscow, Nauka, 205 p.

Aumont, J., Bergala, A., Mari, M., Vernet, M. (2012). Estetika fil'ma [Aesthetics of Film]. Moscow, New literary review, $245 \mathrm{p}$.

Bely, A. (1989). Moskva [Moscow]. Moscow, Sovetskaia Rossiia, 766 p.

Benjamin, W. (1997). Moskovskii dnevnik [Moscow diary]. Moscow, "Ad Marginem”, 221 p.

Eisenstein, S. (1998). Montazh [Editing]. Moscow, VGIK, 192 p.

Flaker, A. (2008). Zhivopisnaia literatura i literaturnaia zhivipis' [Pictorial literature and literary painting]. Moscow, Tri kvadrata, $428 \mathrm{p}$.

Kapustin, V.P. (1995). Na izlete utopii, na izlome inzhinerii: Richard Bakminster Fuller [On the decline of utopia, on the break of engineering: Richard Buckminster fuller], In News of Higher Educational Institutions. Architecton, 1-2, 54-59.

Katsis, L.F. (1999). "Moskovskii chudak" Andreia Belogo, Moskva i "Moskva" Andreia Belogo ["The Moscow eccentric" by Andrei Bely, Moscow and Andrei Bely’s "Moscow"]. Moscow, Izdatel'skii tsentr Rossiiskogo gosudarstvennogo gumanitarnogo universiteta, 137-152.

Mersh, D. Meta/dia. Dva razlichnykh podkhoda $k$ medial'nomu [Meta/dia. Two different approaches to the medial]. Available at: http://mediaphilosophy.ru/biblioteca/articles/mersh $\mathrm{dia} /$

Metts, K. (2010). Voobrazhaemoe oznachaiushee. Psikhoanaliz i kino [The imaginary signifier. Psychoanalysis and cinema]. St. Petersburg, Izdatel'stvo Evropeiskogo universiteta v Sankt-Peterburge, $334 \mathrm{p}$.

Vaiskopf, M. (2003). Ptitsa-troika i kolesnitsa dushi [The Troika bird and the chariot of the soul]. Moscow, New Literary Review, 568 p.

Vattimo, Dzh. (2003). Prozrachnoe obshestvo [Transparent society]. Moscow, Logos, 124 p. 
Zaionts, L.O. (2012). "Govoriashaia priroda" v kino-proektsii Semiona Bobrova ["Speaking nature" in Semyon Bobrov's movie projection]. Universalii russkoi literatury. Vyp. 4 [Universals of Russian literature. Vol. 4]. Voronezh, 258-270.

Zamiatin, D.N. (2004). Metageografia. Prostranstvo obrazov $i$ obrazy prostranstva [Metageography. Space images and images of space]. Moscow, Agraf, $506 \mathrm{p}$.

\title{
Начальная кинориторика: исчисление и глазомер катастрофы
}

\author{
А.П. Люсый, \\ Институт наследия \\ Россия, 129366, Москва, ул. Космонавтов, 2
}

Крымский текст возник как южный полюс петербургского текста. В процессе его генезиса громоздкая поэтика Семена Боброва была поглощена поэтической легкостью Александра Пушкина. Литературная же «кинопоэтика» имеет изначально крымское происхождение, и здесь Бобровостается пока вне конкуренции, особенно впоэтикекатастрофизма. В дальнейшем двум городам в мире оказалась особо присуща мифология самоотрицания - это Петербург и Нью-Йорк. В обоих случаях катастрофизм оказался усилен кинематографизмом. В случае с петербургским и московским текстами это усиление произошло кинематографизмом слова, а не реально осуществившихся экранизачий. В частности, особым кинематографическим мыилением обладал Андрей Бельй, создавший в романах «Петербург» и «Москва» поэтику кино, намного опередившую реальное развитие кинематографа своего и даже намего времени. Парадокс в том, что никто не ставит своей задачей экранизацию романов Белого, ограничиваясь Владимиром Сорокиным, оказавшимся ближе сборной столице, возродившейся, как офисныий и сырьевой Феникс (Москва как Нью-Петербург новой России).

Нью-Йорк же именно благодаря кинематографу давно уже стал символом разрушаемого всевозможными катастрофами города. "11 сентября» не что иное, как символическое повторение многих сюжетов фильмов-катастроф. Воображаемые бедствия до 11.09.2011 компенсируют монотонный ритм повседневности, а после - виртуализируют радикальный опыт и функционируют как эмочиональная защита, сформированная повседневным монотонным ритмом. Впрочем, реакция на сам терракт на государственном уровне оказалась сродни реакиии ковбоев на первые вестерны, стрелявших из зала по экрану. В России катастрофизм не столько кинематографизируется, сколько медийно музеефицируется. Запуск механизма формирования глобального просмотрового зала обозначен в финале фильма Балабанова «Морфий».

Ключевые слова: поэтика, кинориторика, метафора, монтаж, классификации, катастрофа, медиум, текст, киноиндустрия.

Статья подготовлена при поддержке грантов РГНФ: № 15-03-00581 «Освоение репрезентаций пространства в культурных практиках: история и современность» и № 15-33-14106 «Целевые ориентиры государственной начиональной политики: возобновление человеческого ресурса и национальные культуры (проблема Другого)».

Научная специальность: 10.00.00 - филологические науки. 